Zagazig J. Agric. Res., Vol. 43 No. (6A) 2016

http:/www.journals.zu.edu.eg/journalDisplay.aspx?Journalld=1\&queryType=Master

\title{
ENHANCEMENT OF CHROMIUM REMOVAL FROM WATER BY BIO- ADSORPTION USING EDTA-TREATED RICE STRAW
}

\author{
Magdy M. Niazy* \\ Soil, Water and Environ. Res. Inst., Agric. Res. Cent. (ARC), Giza, Egypt
}

\begin{abstract}
Using factorial experiments, rice straw of $1 \mathrm{~g}$ or $2 \mathrm{~g}$ weight was immersed into $100 \mathrm{ml}$ of water solution of different concentrations of $\mathrm{Cr}$ (25, 50 and $75 \mathrm{mg} \mathrm{Crl}$ ), in a form of Cr-chloride ' $\mathrm{CrCl}_{3}$. $6 \mathrm{H}_{2} \mathrm{O}$ '. The contact and shaking time intervals were 60,90 and 120 minutes and the solution $\mathrm{pH}$ values were 5, 7 and 9. One experiment was conducted for each of the $1 \mathrm{~g}$ and $2 \mathrm{~g}$ non- ethylenediamine tetra acetic acid (EDTA)-treated straw and one experiment for each of the 1g and $2 \mathrm{~g}$ EDTA-treated straw. In terms of the amount of $\mathrm{Cr}$ removed from solutions, it increased as the initial concentration increased. In terms (\%) removal from the initial concentration, the removed portions decreased as the initial concentration increased. Treating the straw with EDTA and increasing the time of contact enhanced the removal. High removals occurred with the neutral or alkaline $\mathrm{pH}$. Lowest (\%) removal was $24 \%$ for the treatment of $1 \mathrm{~g}$ non-EDTA straw of the $75 \mathrm{mg}$ Crl solution of $\mathrm{pH} 5$ and the shortest contact time of $60 \mathrm{~min}$. Highest (\%) removal of $100 \%$ was obtained by the treatment of $2 \mathrm{~g}$ EDTA straw in the $25 \mathrm{mg} \mathrm{Crl}$ of either $\mathrm{pH} 7$ or 9 and longest contact time of $120 \mathrm{~min}$.
\end{abstract}

Key words: Adsorption, chromium, rice straw, contact time, pH, EDTA-modified.

\section{INTRODUCTION}

Rapid industrialization in Egypt has created pollution problems of uncontrolled disposal of the wastewater which is potentially dangerous since it contains such as Chromium (Cr). $\mathrm{Cr}$ is a transition metal contaminant that exists in nature primarily as the soluble highly toxic $\mathrm{Cr}$ (VI) anion and the less soluble, less toxic $\mathrm{Cr}$ (III). Its compounds have widespread industrial use such as steel production, wood preservation, leather tanning, metal corrosion inhibition, paints and pigments, metal plating, and other applications. It is a contaminant in certain waters, soils, and sediments, occurring primarily as $\mathrm{Cr}$ (III) or $\mathrm{Cr}$ (VI); the latter being carcinogenic and mutagenic (Priester et al., 2006). Leather and its tanning are the fifth largest industry in Egypt using 125 to 130 million cubic meters per year (Mahmoud, 2009). Leather industry in Egypt is most important representing $5 \%$ of the total industrial production with 300 leather factories employing 250 thousand workers located in the old Cairo (Marina et al., 2012). On the other

\footnotetext{
*Corresponding author: Tel. : +201093458689

E-mail address: amagdy16@gmail.com
}

hand workers in the cement industry have high exposure levels to $\mathrm{Cr}$ VI and one third of the leather workers have severe skin and chest manifestations and one fifth of the cement workers have nasal manifestations (Elhosary et al., 2014). Use of low-cost sorbents such as some agricultural wastes in sorbing heavy metals from waste waters represents environmentally friendly practice (Deans and Dixon, 1992).

The basic components of the agricultural waste materials include hemi cellulose, lignin, lipids, proteins, simple sugars, water, hydrocarbons and starch, containing a variety of functional groups (Bhatnagar and Sillanpää, 2010). Cellulitic agricultural materials have high capacity for absorbing pollutants (Bhatnagar and Jain, 2005). Agricultural wastes are a rich source for activated carbon production due to their low ash content and reasonable hardness (Ahmedna et al., 2000). These materials are used in their natural form or after some physical or chemical modification. Pretreatments are practiced using different kinds of modifying agents such 
treatment with base alkaline sodium hydroxide, calcium hydroxide, sodium carbonate or acidic solutions of hydrochloric, nitric, sulphuric, tartaric, and citric acids or organic compounds such as ethylenediamine, formaldehyde, epichlorohydrin, methanol or the oxidizing agent of hydrogen peroxide (Aydin et al., 2004). The choice of the absorbing materials is based on their easy availability, their source natural (e.g. wood, peat, coal, lignite), byproducts (e.g. slag, sludge, fly ash, bagasse flyash, red mud), and synthic products (Ahmaruzzaman, 2008 ; Gupta et al., 2009). Organic wastes are major sources of problems in the world representing annual 25 million Mg of agroresidues, of which 12 million $\mathrm{Mg}$ are used for heating or for industrial purposes (Allam et al., 2011). In Egypt, rice straw is a main agricultural waste which represents 4 million $\mathrm{Mg}$ annually produced every autumn. It is traditionally disposed of, by burning in situ, causing harmful environmental implications (Yakout and Elsherif, 2010).

The objective of the current study was to assess the practicality of using rice straw to absorb/adsorb $\mathrm{Cr}$ in water of different cocentrations of $\mathrm{Cr}$ using ethylenediamine tetra acetic acid (EDTA) treatment of the straw.

\section{MATERIALS AND METHODS}

Experiments were conducted to evaluate the ability of rice straw as an absorbent of $\mathrm{Cr}$ from $\mathrm{Cr}$ solutions of different concentrations and different time duration and different $\mathrm{pH}$ of the solutions. The design of each experiment was a randomized complete block design, factorial, with 3 factors. The factors were as follows: (1) $\mathrm{Cr}$ concentration in the contact solution, (2) Time duration of contact between straw and solution and (3) the $\mathrm{pH}$ of the solution. $\mathrm{Cr}$ concentrations (in a form of $\mathrm{Cr}$ chloride ' $\mathrm{CrCl}_{3} \cdot 6 \mathrm{H}_{2} \mathrm{O}$ ') were 25,50 and $75 \mathrm{mgl}^{-1}$. Time of duration intervals were 60,90 and $120 \mathrm{~min}$. The $\mathrm{pH}$ values were 5,7 and 9 . Therefore the different treatment combinations were 27 (3 concentrations $\mathrm{X} 3$ time durations $\mathrm{X} 3 \mathrm{pHs}$ ) .Treatments were done in 3 replicates.

The rice straw was either EDTA-treated or non-EDTA-treated. Treatment with EDTA was done as described by Abia et al. (2005). A 30g weight of straw was washed with de-ionized water several times then dried at $50^{\circ} \mathrm{C}$. For EDTA treatment, $17 \mathrm{~g}$ weight of the dried straw refluxed in $300 \mathrm{~mL}$ solution of pyridine and 56.7 g of EDTA for $3 \mathrm{hr}$., at $70^{\circ} \mathrm{C}$. After cooling, an amount of $300 \mathrm{ml}$ deionized water was added and finally the straw was dried for $50^{\circ} \mathrm{C}$ for 12 hr.

Execution of each experiment was done as follows (Jimoh et al., 2011): the straw sample was soaked in $100 \mathrm{ml}$ of $\mathrm{Cr}$ solution of the specified concentration and $\mathrm{pH}$, then shaken for the specified contact time. At end of shaking time, the concentration of $\mathrm{Cr}$ in the solution sample was digested by perchloric, nitric and sulfuric acid mixture (1:5:0.5) (Stewart, 1989)

$\mathrm{Cr}$ in solution samples were determined using an atomic absorption spectrophotometer (AA - Scan I Thermo Jarrell Ash, USA).

. The portion of $\mathrm{Cr}$ removed from the contact solution was calculated as follows (Argun et al., 2007):

$$
\text { Cr removal }(\%)=\left\{\left(\mathrm{Cr}_{\mathrm{i}}-\mathrm{Cr}_{\mathrm{f}}\right) \div \mathrm{Cr}_{\mathrm{i}}\right\} \times 100
$$

Where $\mathrm{Cr}_{i}$ is the initial $\mathrm{Cr}$ concentration of the contact solution and $\mathrm{Cr}_{\mathrm{f}}$ is the concentration at end of the contact time interval. Such removal indicates the extent of efficiency of the straw as an absorbent of $\mathrm{Cr}$ from the solution.

One experiment was done for each of the followings (1) non-EDTA-treated straw and (2) EDTA- treated straw, (3) using straw weight of $1 \mathrm{~g}$ and (4) using straw weight of $2 \mathrm{~g}$ to be submerged in $100 \mathrm{ml}$ of Cr-containing water solutions.

\section{RESULTS AND DISCUSSION}

There were positive responses due to treatments. The main effects (1) Cr concentration of the contact solution, (2) $\mathrm{pH}$ of the solution and (3) the initial concentration of solution are shown in Table 1.

\section{Main Effect of Contact Time}

Increased contact time was associated with increased removal of $\mathrm{Cr}$ from the contact solution. The increased removal was progressive ranging from about 31 to $46 \%$ for the $1 \mathrm{~g}$ nonEDTA sample upon increasing the contact time from 60 to $120 \mathrm{~min}$. The EDTA-treated sample 
Table 1. Final concentration (F.conc.) of $\mathrm{Cr}$ in solution contacting rice straw $\left(\mathrm{mgl}^{-1}\right)$ and (\%) $\mathrm{Cr}$ removal from initial solution as affected by contact time, solution $\mathrm{pH}$ and initial $\mathrm{Cr}$ concentration using EDTA-treated and non-treated rice straw absorbent ( $1 \mathrm{~g}$ and $2 \mathrm{~g}$ ) straw samples (main effects)

\begin{tabular}{|c|c|c|c|c|c|c|c|c|}
\hline \multirow[b]{3}{*}{ pH } & \multicolumn{4}{|c|}{$1 \mathrm{~g}$ rice straw } & \multicolumn{4}{|c|}{2 g rice straw } \\
\hline & \multicolumn{2}{|c|}{ Non-EDTA-treated } & \multicolumn{2}{|c|}{ EDTA-treated } & \multicolumn{2}{|c|}{ Non-EDTA-treated } & \multicolumn{2}{|c|}{ EDTA-treated } \\
\hline & F.conc. & $\begin{array}{c}\text { Removal } \\
(\%)\end{array}$ & F.conc. & $\begin{array}{c}\text { Removal } \\
\text { (\%) }\end{array}$ & F.conc. & $\begin{array}{c}\text { Removal } \\
(\%)\end{array}$ & F.conc. & $\begin{array}{c}\text { Removal } \\
(\%)\end{array}$ \\
\hline \multicolumn{9}{|c|}{ Contact time (min) } \\
\hline 60 & 34.73 & 31.31 & 20.42 & 61.55 & 27.28 & 46.89 & 8.11 & 84.90 \\
\hline 90 & 31.97 & 32.50 & 15.47 & 70.77 & 22.67 & 56.18 & 4.76 & 91.51 \\
\hline 120 & 29.26 & 43.30 & 11.92 & 78.06 & 16.97 & 67.70 & 2.67 & 96.29 \\
\hline LSD 5\% & 0.57 & 0.63 & 0.57 & 0.57 & 0.57 & 0.57 & 1.01 & 0.57 \\
\hline LSD 1\% & 0.75 & 0.84 & 0.75 & 0.75 & 0.75 & 0.75 & 1.35 & 0.75 \\
\hline \multicolumn{9}{|c|}{ pH } \\
\hline 5 & 34.55 & 31.73 & 20.98 & 60.86 & 25.58 & 50.08 & 7.81 & 85.46 \\
\hline 7 & 31.90 & 37.47 & 14.80 & 72.17 & 22.41 & 57.12 & 4.36 & 92.62 \\
\hline 9 & 29.51 & 37.91 & 12.02 & 77.36 & 18.93 & 63.58 & 3.37 & 94.61 \\
\hline LSD 5\% & 0.57 & 0.63 & 0.57 & 0.57 & 0.57 & 0.57 & 1.01 & 0.57 \\
\hline LSD 1\% & 0.75 & 0.84 & 0.75 & 0.75 & 0.75 & 0.75 & 1.35 & 0.75 \\
\hline \multicolumn{9}{|c|}{ Cr concentration ( $\mathrm{mg} \mathrm{l}^{-1}$ ) } \\
\hline 25 & 14.60 & 41.50 & 5.62 & 77.48 & 9.31 & 62.73 & 1.87 & 94.16 \\
\hline 50 & 31.04 & 36.94 & 14.77 & 69.45 & 21.33 & 56.32 & 4.25 & 91.09 \\
\hline 75 & 50.32 & 28.67 & 27.41 & 63.45 & 36.28 & 51.72 & 9.42 & 87.44 \\
\hline LSD 5\% & 0.57 & 0.63 & 0.57 & 0.57 & 0.57 & 0.57 & 1.01 & 0.57 \\
\hline LSD $1 \%$ & 0.75 & 0.84 & 0.75 & 0.75 & 0.75 & 0.75 & 1.35 & 0.75 \\
\hline
\end{tabular}

Notes: Straw samples were immersed in $100 \mathrm{ml}$ of solution and shaken for the specified time.

showed greater removal ranging from 62 to $78 \%$ reflecting the considerable effect of EDTA on increasing the removal of $\mathrm{Cr}$. Results of the $2 \mathrm{~g}$ sample showed much greater removal of $\mathrm{Cr}$ from the initial solution with comparable removals 47 to $67 \%$ for the non-EDTA-treated and 85 to $96 \%$ for the EDTA-treated straw. This shows that the more time allowed for contact of straw allows the straw to retain more $\mathrm{Cr}$ from the solution, and that the EDTA facilitates chelating of $\mathrm{Cr}$ from the solution.
These also indicate that increases amount of straw allows retaining increases amounts of $\mathrm{Cr}$. These results are in agreement with those of Babel and Kurniawan (2004) who removed Cr from waste water using coconut shell charcoal and commercial activated carbon.

\section{Main Effect of pH}

Increased $\mathrm{pH}$ from 5 to 7 caused a marked increase in (\%) removal of Cr. Average removals were 32 and $37 \%$ at above-mentioned 
$\mathrm{pH}$ values, respectively for the non-EDTAtreated straw of $1 \mathrm{~g}$ sample. Comparable removals for the EDTA-treated straw were much higher giving 61 and 72\%, respectively. The removal was greater with the $2 \mathrm{~g}$ sample: 50 and $57 \%$, respectively for the non-EDTA-treated straw and 85 and 93\%, respectively for the EDTA-treated straw. The increase of removal at $\mathrm{pH} 9$ was slightly greater than that given by the $\mathrm{pH} 7$ indicating that the $\mathrm{pH} 7$ is most appropriate for increasing $\mathrm{Cr}$ removal from the solution.

Chromium removal was shown by Dakiky et al. (2002), Kalavathy and Miranda (2010) and Sharma et al. (2006) to increase by increased $\mathrm{pH}$. On the other hand, Ahluwalia and Goyal (2007) noted that heavy metal removal decreased upon decreasing the $\mathrm{pH}$ of the solution from 6 to 2 and that in the $\mathrm{pH}$ range of 2.5 to 5 , binding of heavy metal cations was determined primarily by dissociation of the weak acidic groups. Kratochvil and Volesky (1998) reported that at low $\mathrm{pH}$ the hydrogen and hydronium ions are high and compete with metal ions for the binding sites causing low metal uptake by plant, while at high $\mathrm{pH}$ of 5 to 7 , the competing hydrogen ions are low in number.

Abia et al. (2005) and Wan et al. (2006) used rice straw modified by EDTA caused and obtained increases the adsorbed metal ion concentration, ions adsorbed increased as the initial concentration increased. The EDTA treatment enhanced the adsorption capacity of maize husk due to the chelating ability of EDTA.

\section{Main Effect of Initial Cr Concentrations in the Contacting Solution}

Although increased concentration of the solution was associated with increased removal of the amount of $\mathrm{Cr}$ removed from the solution, the removal in terms of portion of the initial concentration decreased. For example regarding the non-EDTA-treated $1 \mathrm{~g}$ sample, the final $\mathrm{Cr}$ concentration averaged $15 \mathrm{mgl}^{-1}$ for the initial solution of $25 \mathrm{mgl}^{-1}$, increasing progressively reaching a highest level of $50 \mathrm{mgl}^{-1}$ for the solution of the highest initial concentration of $\mathrm{mgl}^{-1}$ averaged. But in terms of (\%) removal the portions of removal decreased with the increase in initial concentration. The parallel progressive decrease of (\%) removal averaged 42, 37 and $29 \%$ for the low, medium and high concentration solutions, respectively. Although the progressive decrease in the (\%) removal Cr was not exactly parallel to the progressive increase in the final concentration of $\mathrm{Cr}$, it was very much near the exact parallel. This is predictable since the extent of decrease in the final solution was not considerable enough to allow such status. The pattern of response with regard to the EDTAtreated $1 \mathrm{~g}$ straw was rather similar to that of the non-EDTA-treated one, but the positive effect of EDTA was very much considerable in decreasing the final concentration of Cr. The $2 \mathrm{~g}$ samples showed higher removal of $\mathrm{Cr}$ reaching an overall average of 87 to 94 reflecting the high efficiency of the greater amount of straw in removing $\mathrm{Cr}$ from waste waters. Coupal and Lalancette (1976) reported high removal of heavy metals using peat materials.

\section{Interaction Effect of Contact Time and pH of Solution}

The increase of (\%) removal of $\mathrm{Cr}$ was progressive with the increase of the contact time of particularly with $\mathrm{pH} 7$ or 9 (Table 2). For example the average (\%) $\mathrm{Cr}$ removal for the solution soaking the $1 \mathrm{~g}$ non-EDTA-treated straw was about 31, 32 and $43 \%$ for the 60,90 and 120 -min contact intervals, respectively. The increased pattern was more marked under conditions of the $\mathrm{pH} 7$; being 32, 37 and $43 \%$ for the same time intervals, respectively. The pattern of response regarding the EDTA-treated straw was rather similar to the non-EDTAtreated but with considerable magnitudes. Average (\%) removal for solution of the $1 \mathrm{~g}$ EDTA-treated straw was 47, 56 and 68, respectively indicating similar trend of the time of contact but with greater magnitude, and reflecting the considerable positive effect of EDTA treatment in removing $\mathrm{Cr}$ from the water. The removal under $\mathrm{pH} 9$ was most marked, being 54, 65 and 71\%, respectively. Results for the $2 g$ straw weight show more positive effects in view of the higher amount of the straw absorbent. Aydin et al. (2004) demonstrated the high efficiency of low-cost cellulitic materials in absorbing heavy metals from waters. 
Table 2. Final concentration of $\mathrm{Cr}$ in solution contacting rice straw $\left(\mathrm{mgl}^{-1}\right)$ and (\%) $\mathrm{Cr}$ removal from initial solution as affected by contact time, solution $\mathrm{pH}$ and initial $\mathrm{Cr}$ concentration using EDTA-treated and non-treated rice straw of $1 \mathrm{~g}$ and $2 \mathrm{~g}$ samples (interaction effect of contact time ' $\mathrm{T}$ ' and $\mathrm{pH}$ ) *

\begin{tabular}{|c|c|c|c|c|c|c|c|c|c|c|c|c|}
\hline \multirow[b]{3}{*}{ pH } & \multicolumn{6}{|c|}{1 g rice straw } & \multicolumn{6}{|c|}{$2 \mathrm{~g}$ rice straw } \\
\hline & \multicolumn{3}{|c|}{ 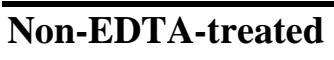 } & \multicolumn{3}{|c|}{ EDTA-treated } & \multicolumn{3}{|c|}{ 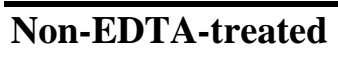 } & \multicolumn{3}{|c|}{ EDTA-treated } \\
\hline & 60 & 90 & 120 & 60 & 90 & 120 & 60 & 90 & 120 & 60 & 90 & 120 \\
\hline & \multicolumn{12}{|c|}{ Cr concentration in final solution $\left(\mathrm{mgL}^{-1}\right)$ following 60 to 90 min contact time } \\
\hline 5 & 36.87 & 34.75 & 32.02 & 31.46 & 26.54 & 18.76 & 25.86 & 20.83 & 16.26 & 10.73 & 7.86 & 4.67 \\
\hline 7 & 34.54 & 31.82 & 29.34 & 27.15 & 23.13 & 16.96 & 19.04 & 14.40 & 10.97 & 7.23 & 3.95 & 1.27 \\
\hline 9 & 32.79 & 29.33 & 26.41 & 23.24 & 18.35 & 15.20 & 16.36 & 11.17 & 8.54 & 6.38 & 2.18 & 1.00 \\
\hline LSD at & 0.05 & 0.01 & & 0.05 & 0.01 & & 0.05 & 0.01 & & 0.05 & 0.01 & \\
\hline \multicolumn{3}{|l|}{ For: T x pH } & & 0.98 & 1.30 & & 0.98 & & & & & \\
\hline & \multicolumn{12}{|c|}{ (\%) removal of $\mathrm{Cr}$ (removed from the initial solution) } \\
\hline 5 & 26.69 & 30.90 & 37.59 & 38.29 & 47.90 & 64.06 & 51.55 & 60.85 & 70.18 & 79.49 & 85.38 & 91.52 \\
\hline 7 & 31.82 & 37.42 & 43.16 & 47.46 & 56.09 & 67.80 & 63.97 & 72.77 & 79.78 & 86.58 & 92.78 & 98.49 \\
\hline 9 & 35.42 & 29.01 & 49.16 & 54.92 & 64.56 & 71.26 & 69.14 & 78.70 & 84.23 & 88.63 & 96.36 & 98.86 \\
\hline LSD at & 0.05 & 0.01 & & 0.05 & 0.01 & & 0.05 & 0.01 & & 0.05 & 0.01 & \\
\hline For: T $\mathbf{x} \mathbf{p H}$ & 1.09 & 1.45 & & 0.98 & 1.30 & & 0.98 & 1.30 & & 0.98 & 1.30 & \\
\hline
\end{tabular}

*See footnotes of Table 1

\section{Interaction Effect of Contact Time and Cr of the Initial Solution}

In terms of $\mathrm{mg} \mathrm{Cr} \mathrm{l}^{-1}$, the removal was greater as the initial concentration of $\mathrm{Cr}$ was higher (Table 3). The $\mathrm{Cr}$ concentration in the final solution soaking the non-EDTA $1 \mathrm{~g}$ straw

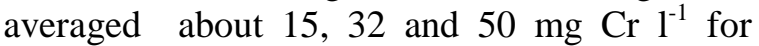
treatments of initial solution of 25,50 and 75 $\mathrm{Cr} \mathrm{l}^{-1}$, indicating a removal of 10, 18 and $25 \mathrm{mg}$ $\mathrm{Cr} \mathrm{l}^{-1}$ from such solutions, respectively. The amount of removal was much greater where the contact time was longest (13, 22 and $28 \mathrm{mg} \mathrm{Cr} \mathrm{l}^{-1}$, respectively for the 120-min time) and much smaller where the contact time was shortest ( 9 , 16 and $11 \mathrm{mg} \mathrm{Cr} \mathrm{l}^{-1}$, respectively for the 60 -min contact time). However in terms of (\%) removal it was the low initial concentration which showed greater portion of removal. Such results demonstrate the expected response of low versus high initial concentration of pollutes in waste waters. The EDTA and the higher weight of straw raised the efficiency of removal. A highest removal of $99 \%$ was given by the $2 g$ EDTA straw where the initial $\mathrm{Cr}$ concentration was lowest, i.e., for the $25 \mathrm{mg} \mathrm{Cr} \mathrm{l}^{-1}$ solution.

\section{Interaction Effect of $\mathrm{Cr}$ and $\mathrm{pH}$ of the Initial Solution}

The increase in $\mathrm{Cr}$ concentration in final solution which was associated with the increase in $\mathrm{Cr}$ concentration of the initial solution occurred under all conditions of $\mathrm{pH}$, particularly pH 9 (Table 4). For example the average $\mathrm{Cr}$ in solution soaking the $1 \mathrm{~g}$ non-EDTA-treated straw was about 15, 31 and $50 \mathrm{mg} \mathrm{l}^{-1}$ in solutions of $\mathrm{Cr}$ of 25,50 and $75 \mathrm{mg} \mathrm{l}^{-1}$, respectively indicate removals of 10, 19 and $25 \mathrm{mg} \mathrm{l}^{-1}$ (i.e., 40, 38 and $33 \%)$ from the respective solutions. Where the $\mathrm{pH}$ was 9 the comparable removals were more, being 12, 22 and $28 \mathrm{mg} \mathrm{l}^{-1}$ (i.e. 48, 44 and 37\%), respectively. Thus in terms of (\%) $\mathrm{Cr}$ removal relating initial status, the pattern was not exactly 
Table 3. Final concentration of $\mathrm{Cr}$ in solution contacting rice straw $\left(\mathrm{mgl}^{-1}\right)$ and $\% \mathrm{Cr}$ removal from initial solution as affected by contact time, solution $\mathrm{pH}$ and initial $\mathrm{Cr}$ concentration using EDTA-treated and non-treated rice straw of $1 \mathrm{~g}$ and $2 \mathrm{~g}$ straw samples (interaction effect of contact time ' $T$ ' and initial solution $\mathrm{Cr}$ concentration)*

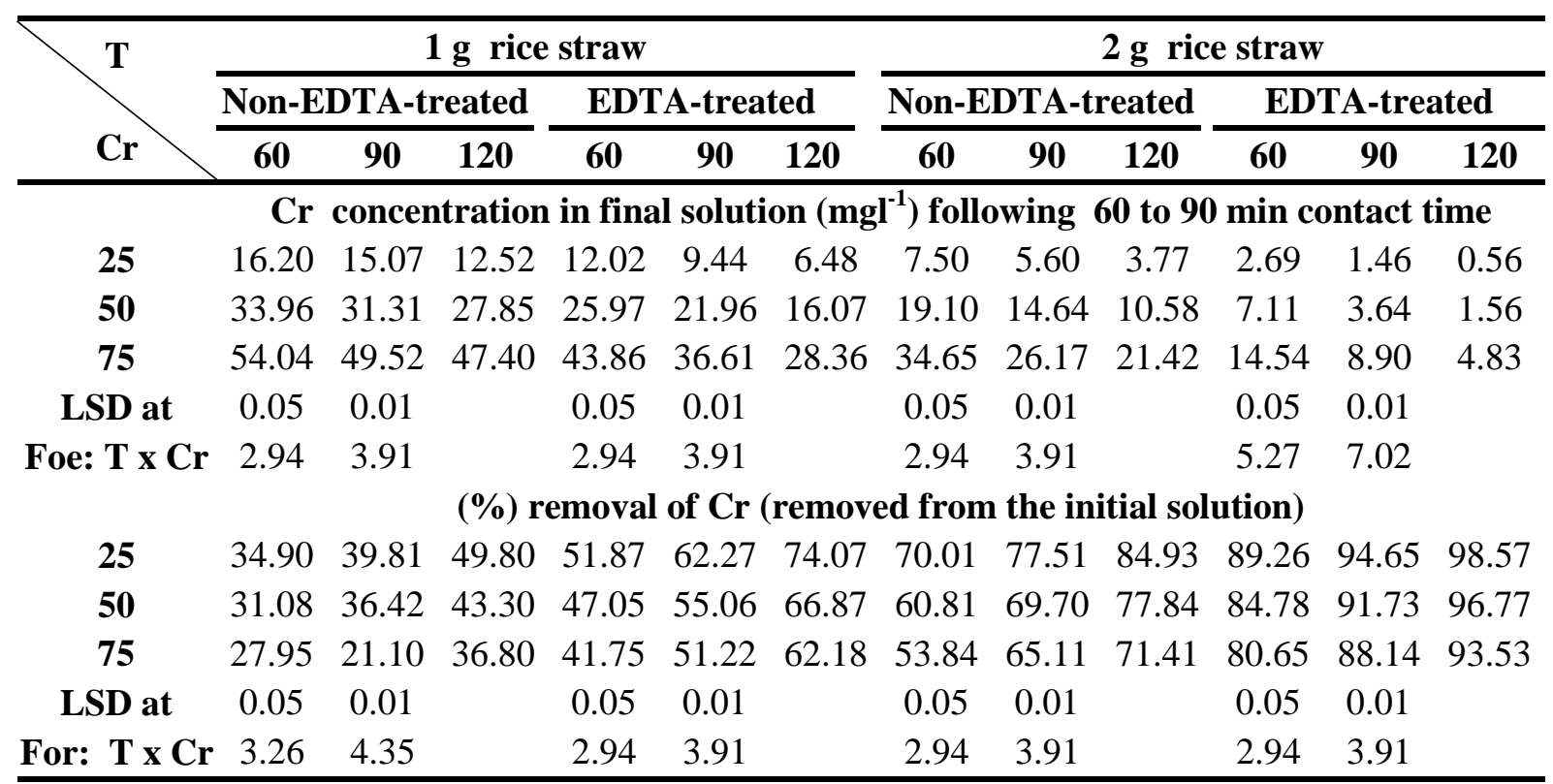

*See footnotes of Table 1

Table 4. Final concentration of $\mathrm{Cr}$ in solution contacting rice straw $\left(\mathrm{mg} \mathrm{l}^{-1}\right)$ and (\%) $\mathrm{Cr}$ removal from initial solution as affected by contact time, solution $\mathrm{pH}$ and initial $\mathrm{Cr}$ concentration using EDTA-treated and non-treated rice straw of $1 \mathrm{~g}$ and $2 \mathrm{~g}$ straw samples (interaction effect of and initial solution $\mathrm{Cr}$ concentration ' $\mathrm{Cr}$ ' and its $\mathrm{pH}$ )*

\begin{tabular}{|c|c|c|c|c|c|c|c|c|c|c|c|c|}
\hline \multirow[b]{3}{*}{$\mathbf{p H}$} & \multicolumn{6}{|c|}{1 g rice straw } & \multicolumn{6}{|c|}{$2 \mathrm{~g}$ rice straw } \\
\hline & \multicolumn{3}{|c|}{ Non-EDTA-treated } & \multicolumn{3}{|c|}{ EDTA-treated } & \multicolumn{3}{|c|}{ Non-EDTA-treated } & \multicolumn{3}{|c|}{ EDTA-treated } \\
\hline & 25 & 50 & 75 & 25 & 50 & 75 & 25 & 50 & 75 & 25 & 50 & 75 \\
\hline & \multicolumn{12}{|c|}{ Final $\mathrm{Cr}$ concentration $\left(\mathrm{mg} \mathrm{l}^{-1}\right)$ in contact solutions of initial 25 to $75 \mathrm{mg} \mathrm{Cr} \mathrm{l}^{-1}$} \\
\hline 5 & 16.04 & 33.80 & 53.80 & 11.22 & 24.83 & 40.70 & 7.32 & 19.47 & 36.16 & 2.62 & 6.75 & 13.89 \\
\hline 7 & 14.38 & 30.92 & 50.40 & 9.01 & 21.28 & 36.94 & 5.31 & 13.66 & 25.44 & 1.23 & 3.32 & 7.91 \\
\hline 9 & 13.37 & 28.40 & 46.76 & 7.71 & 17.88 & 31.19 & 4.23 & 11.19 & 20.65 & 0.86 & 2.24 & 6.46 \\
\hline LSD at & 0.05 & 0.01 & & 0.05 & 0.01 & & 0.05 & 0.01 & & 0.05 & 0.01 & \\
\hline \multirow[t]{2}{*}{ For: Cr x pH } & 0.98 & 1.30 & & 0.98 & 1.30 & & 0.98 & 1.30 & & 1.76 & 2.34 & \\
\hline & \multicolumn{12}{|c|}{ (\%) removal of $\mathrm{Cr}$ (removed from the initial solution) } \\
\hline 5 & 35.51 & 31.40 & 28.27 & 55.13 & 49.34 & 45.77 & 70.71 & 60.07 & 51.80 & 89.44 & 85.50 & 81.45 \\
\hline 7 & 42.43 & 37.17 & 32.80 & 63.97 & 56.41 & 50.97 & 78.77 & 71.69 & 66.06 & 95.55 & 92.81 & 89.48 \\
\hline 9 & 46.57 & 42.24 & 24.78 & 69.10 & 63.22 & 58.41 & 82.97 & 76.59 & 72.51 & 97.48 & 94.97 & 91.39 \\
\hline LSD at & 0.05 & 0.01 & & 0.05 & 0.01 & & 0.05 & 0.01 & & 0.05 & 0.01 & \\
\hline For: Cr x pH & 1.09 & 1.45 & & 0.98 & 1.30 & & 0.98 & 1.30 & & 0.98 & & \\
\hline
\end{tabular}

*See footnotes of Table 1 
in line with that of the concentration since differences among the initial concentrations were big. The response regarding the EDTAtreated straw more than for the non-EDTAtreated and much greater where the straw weight was $2 \mathrm{~g}$. The most effective removals was $97 \%$ caused by the treatment of initial concentration of $75 \mathrm{mg} \mathrm{l}^{-1}$ soaking $2 \mathrm{~g}$ EDTA-treated straw.

\section{Conclusion}

Rice straw proved a very highly efficient material for $\mathrm{Cr}$ removal from waters, particularly with treatment by EDTA which increased its efficiency by about $50 \%$. The more duration of the contact time between the waste water and the straw, the greater is the removal.
The less the initial concentration of the metal in the water, the more effective is the removal. Using greater amount of straw increases the efficiency. Where the $\mathrm{pH}$ of the solution was 7 or the removal was rather high. The results of the complete combination treatments are shown in Table 5. The complete removal of $100 \%$ occurred in the 2g EDTA-treated straw having the following combinations: initial $\mathrm{Cr}$ of 25 or $50 \mathrm{mg} \mathrm{l}^{-1}$, contact time of $120 \mathrm{~min}$ and at $\mathrm{pH} 7$ or 9 . Hence, rice straw, particularly treated with EDTA is an efficient friendly adsorbent of heavy metals in waste waters. Therefore for removing $\mathrm{Cr}$ from waste waters, a very effective low-cost method is merge rice straw treated with EDTA into such water for a long time and at a wide ratio of straw: water.

Table 5. Final concentration of $\mathrm{Cr}$ (f.Cr) in solution contacting rice straw $\left(\mathrm{mgl}^{-1}\right)$ and (\%) $\mathrm{Cr}$ removal from initial solution as affected by contact time ' $\mathrm{T}$ ', solution $\mathrm{pH}$ and initial $\mathrm{Cr}$ concentration $(\mathrm{Cr})$ using EDTA-treated and non-treated rice straw:

a: Results of all treatment combinations for the $1 \mathrm{~g}$ straw weight

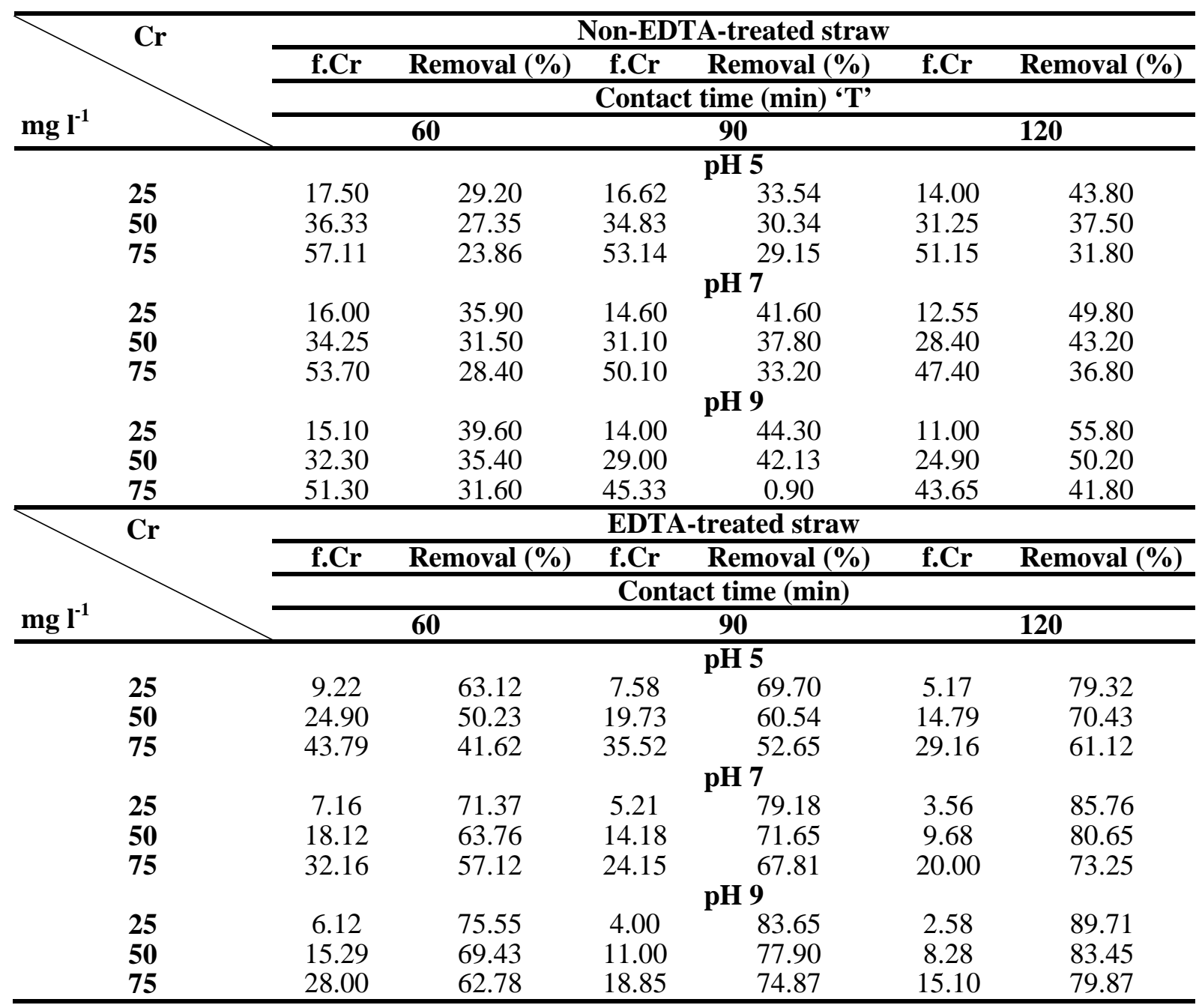


b: Results of all treatment combinations for the $2 \mathrm{~g}$ straw weight

\begin{tabular}{|c|c|c|c|c|c|c|}
\hline \multirow{4}{*}{$\mathrm{mg} \mathrm{l}^{-1}$} & \multicolumn{6}{|c|}{ Non-EDTA-treated straw } \\
\hline & f.Cr & Removal (\%) & f.Cr & Removal (\%) & f.Cr & Removal (\%) \\
\hline & \multicolumn{6}{|c|}{ Contact time (min) ' $T$ ' } \\
\hline & \multicolumn{2}{|r|}{60} & \multicolumn{2}{|r|}{90} & \multicolumn{2}{|r|}{120} \\
\hline & \multicolumn{6}{|c|}{ pH 5} \\
\hline 25 & 14.25 & 43.00 & 12.10 & 51.60 & 7.30 & 70.80 \\
\hline 50 & 30.80 & 38.40 & 25.84 & 48.33 & 18.85 & 62.30 \\
\hline \multirow[t]{2}{*}{75} & 49.65 & 33.80 & 42.00 & 44.10 & 30.45 & 59.40 \\
\hline & \multicolumn{6}{|c|}{ pH 7} \\
\hline 25 & 11.80 & 52.80 & 8.68 & 65.30 & 6.55 & 73.80 \\
\hline 50 & 26.20 & 47.60 & 22.90 & 54.14 & 15.75 & 68.50 \\
\hline \multirow[t]{2}{*}{75} & 43.78 & 42.30 & 38.13 & 49.17 & 28.90 & 61.43 \\
\hline & \multicolumn{6}{|c|}{ pH 9} \\
\hline 25 & 10.00 & 59.80 & 7.53 & 69.90 & 5.60 & 77.60 \\
\hline 50 & 21.90 & 56.15 & 18.15 & 63.70 & 14.60 & 70.80 \\
\hline 75 & 38.15 & 49.14 & 29.70 & 60.40 & 25.73 & 65.70 \\
\hline \multirow{4}{*}{$\mathrm{mg} \mathrm{l}^{-1}$} & \multicolumn{6}{|c|}{ EDTA-treated straw } \\
\hline & \multicolumn{2}{|c|}{ Removal (\%) } & f.Cr & Removal (\%) & \multicolumn{2}{|c|}{$\begin{array}{c}\text { f.Cr Removal } \\
(\%)\end{array}$} \\
\hline & \multicolumn{6}{|c|}{ Contact time(min) } \\
\hline & 60 & & & 90 & & 120 \\
\hline & \multicolumn{6}{|c|}{ pH 5} \\
\hline 25 & 4.14 & 83.45 & 2.71 & 89.17 & 1.00 & 95.70 \\
\hline 50 & 10.23 & 79.54 & 6.68 & 86.65 & 4.35 & 91.30 \\
\hline \multirow[t]{2}{*}{75} & 18.15 & 75.80 & 14.52 & 80.65 & 9.00 & 87.90 \\
\hline & \multicolumn{6}{|c|}{ pH 7} \\
\hline 25 & 2.35 & 90.65 & 1.00 & 96.00 & 0.00 & 100.00 \\
\hline 50 & 6.68 & 86.64 & 3.60 & 92.80 & 0.00 & 100.00 \\
\hline \multirow[t]{2}{*}{75} & 13.00 & 82.77 & 7.59 & 89.88 & 3.15 & 95.80 \\
\hline & \multicolumn{6}{|c|}{ pH 9} \\
\hline 25 & 1.59 & 93.67 & 0.50 & 98.77 & 0.00 & 100.00 \\
\hline 50 & 5.42 & 89.17 & 1.63 & 96.74 & 0.00 & 100.00 \\
\hline 75 & 12.46 & 83.39 & 4.59 & 93.89 & 2.33 & 96.90 \\
\hline
\end{tabular}




\section{REFERENCES}

Abia, A.A., O.C. Okpareke and J.C. Igwe (2005). Sorption kinetics and intraparticulate diffusivities of Co, Fe and Cuions on EDTAmodified maize cob. Int. J. Chem., 15 (3): 187-191.

Ahluwalia, S.S. and D. Goyal (2007). Microbial and plant derived biomass for removal of heavy metals from waste water. Bioresource Technol., 98 (12): 2243-225.

Ahmaruzzaman, M.D. (2008). Adsorption of phenolic compounds on low-cost adsorbents: A review. Adv. Colloid Int. Sci., 143:48-67.

Ahmedna, M., W.E. Marshall and R.M. Rao (2000). Production of granular activated carbons from selected agricultural byproducts and evaluation of their physical, chemical and adsorption properties. Biores. Tech., 71:113-123.

Allam, M.E., L.G. Gihan and H.G. El-Kady (2011). Recycled chopped rice strawcementbricks :mechanical, fire resistance and economical assessment. Aust. J. Basic Appl. Sci., 5 (2): 27-33.

Argun, M.E., S. Dursun, C. Ozdemir and M. Karatas (2007). Heavy metal adsorption by modified oak sawdust: Thermodynamics and kinetics. J. Hazard. Mat., 141:77-85.

Aydin, A.H., Y. Bulut and O. Yavuz (2004). Acid dyes removal using low cost adsorbents. Int. J. Environ. Poll., 21:97-104.

Babel, S. and T.A. Kurniawan (2004). Cr (VI) removal from synthetic wastewater using coconut shell charcoal and commercial activated carbon modified with oxidizing agents and/or chitosan. Chemosphere, 54 : 951 - 967.

Bhatnagar, A. and A.K. Jain (2005). A comparative adsorption study with different industrial wastes as adsorbents for the removal of cationic dyes from water. J. Colloid Int. Sci., $281: 49-55$.

Bhatnagar, A. and M. Sillanpää (2010). Utilization of agro-industrial and municipal waste materials as potential adsorbents for water treatment: A review. Chem. Eng. J., 157: 277-296.
Coupal, B. and J. Lalancette (1976). The treatment of wastewaters with peat moss, Water Res., 10: 1071-1076.

Deans, J.R. and B.G. Dixon (1992). Uptake of $\mathrm{Pb}^{2+}$ and $\mathrm{Cu}^{2+}$ by novel biopolymers. Water Res., 26 (4): 469-472.

Dakiky, M., M. Khamis and A. Manassra (2002). Selective adsorption of chromium (VI) in industrial wastewater using low-cost abundantly available adsorbents. Adv. Environ. Res., 6: 533-540.

Elhosary, N., A. Maklad, E. Soliman, N. ElAshmawy and M. Oreby (2014). Evaluation of oxidative stress and DNA damage in cement and tannery workers in Egypt. Inhalation Toxicol., 26 : 289-298.

Gupta, V.K., P.J.M. Carrott, M.M.L. RibeiroCarrott and T.L. Suhas (2009) Low-cost adsorbents: growing approach to wastewater treatment; A Rev. Crit. Rev. Env. Sci. Technol., 39:783-842.

Jimoh, T., J.N. Egila, B.E.N. Dauda and Y. A. Iyaka (2011). Agricultural waste as a low cost adsorbent for heavy metal removal from wastewater. Int. J. Physical Sci., 6 (8): 21522157.

Kalavathy, H.M. and L.R. Miranda (2010). Moringa oleifera a solid phase extractant for the removal of copper, nickel and zinc from aqueous solutions. Chem. Eng. J., 58 (2): 188-199.

Kratochvil, D. and B. Volesky (1998). Advances in the bio-sorption of heavy metals. Trends in Biotechnol., 16 (7): 291-300.

Mahmoud, R.M. (2009). Tanneries wastewater treatment. Ph.D. Thesis, Fac. Eng., Menoufiya Univ., Egypt.

Marina, A., S. Noha and K. Seven (2012). Strategy development. Case Studies, MENA J. Bus.

Priester, J.H., S.G. Olson, S.M. Webb, M.P. Neu, L.E. Hersman and P.A. Holden (2006). Enhanced exopolymer production and chromium stabilization in Pseudomonas putida unsaturated biofilms. Appl. Environ. Microbiol., 72 : 1988-1996 
Sharma, P., P. Kumari, M.M. Srivastava and S. Srivastava (2006). Removal of cadmium from aqueous system by shelled Moringa oleifera Lam. seed powder. Biores. Tech., 7 (2) : 299-305.

Stewart, E. A. (1989): Chemical analysis of Ecological Materials Ed2. Blackwell scientific publications, Oxford, London, Edinburgh.
Wan, W., S. Ngah, A. Kamari, S. Fatinathan and P.W. Ng (2006). Adsorption of chromium from aqueous solution using chitosan beads. Adsorption, 2 : 249-257.

Yakout, S.M. and E. Elsherif (2010). Batch kinetics, isotherm and thermodynamic studies of adsorption of strontium from aqueous solutions onto low cost rice-straw based carbons. Carbon Sci. Technol., 1 : 144153.

\section{تعزيز إزالة الكروم من المياه بواسطة الإدمصاص باستخدام قش الأرز المعامل بالفرسبن

$$
\begin{aligned}
& \text { مجدى محمد نيازي } \\
& \text { معهد بحوث الأر اضي و المياه والبيئة ـ مركز البحوث الزر اعية ـ الجيزة ـ مصر }
\end{aligned}
$$

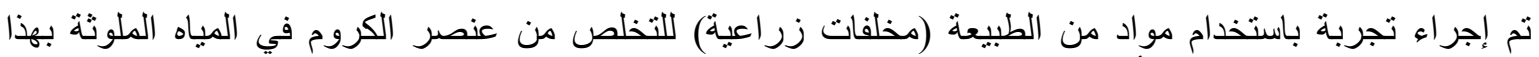

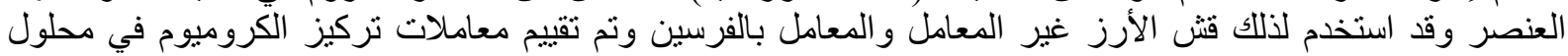

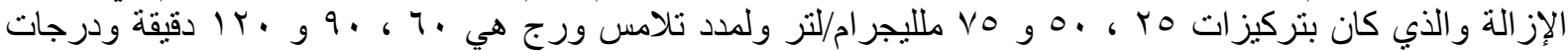

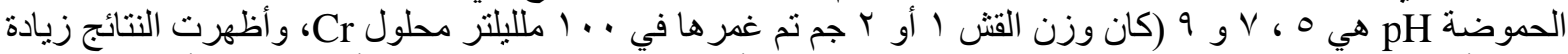

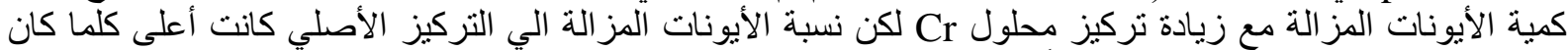

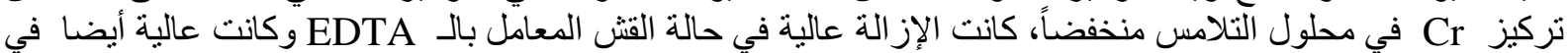

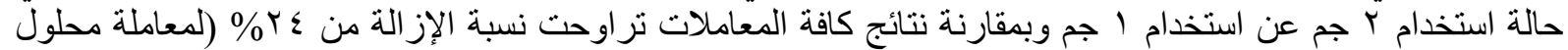

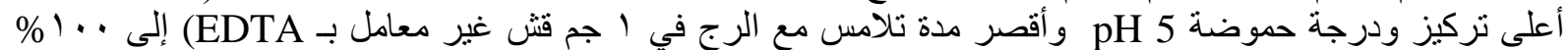

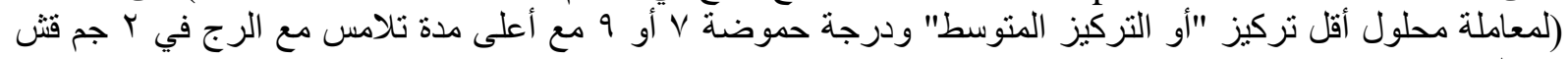

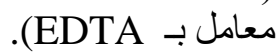

أستاذ الأر اضي المتفرغ - زر اعة مشتهر - جامعة بنها. أستاذ الأر اضي المتفرغ - كلية الزر اعة - ماعة - جامعة الزقازيق. 